Nevis, St Lucia, St Vincent and the Grenadines, Samoa, São Tomé and Príncipe, Senegal, Serbia, Seychelles, Sierra Leone, Slovakia, Slovenia, Solomon Islands, Somalia, South Africa, South Sudan, Spain, Sri Lanka, Sudan, Suriname, Swaziland, Sweden, Switzerland, Tajikistan, United Republic of Tanzania, Thailand, Timor-Leste, Togo, Tonga, Trinidad and Tobago, Tunisia, Turkey, Turkmenistan, Tuvalu, Uganda, Ukraine, UK, USA, Uruguay, Vanuatu, Venezuela, Vietnam, Yemen, Zambia and Zimbabwe. A further eight countries have observer status as do numerous international and non-governmental organizations.

Activities. IOM works to help ensure the orderly and humane management of migration, to promote international co-operation on migration issues, to assist in the search for practical solutions to migration problems and to provide humanitarian assistance to migrants in need, be they refugees, displaced persons or other uprooted people. The IOM Constitution gives explicit recognition to the link between migration and economic, social and cultural development, as well as to the right of freedom of movement of persons. IOM's programme budget for 2014 exceeded US $\$ 1.4 \mathrm{bn}$., funding over 2,400 active programmes and about 9,100 staff members serving in around 400 field offices in more than 150 countries.

Official languages: English, French and Spanish.

Headquarters: Route des Morillons 17, POB 17,

CH-1211 Geneva 19, Switzerland.

Website: http://www.iom.int

Email: hq@iom.int

Director-General: William Lacy Swing (USA).

\section{International Organization for Standardization (ISO)}

Established in 1947, the International Organization for Standardization is a non-governmental federation of national standards bodies from 162 countries worldwide, one from each country. ISO's work results in international agreements which are published as International Standards. The first ISO standard was published in 1951 with the title 'Standard reference temperature for industrial length measurement'.

Some 19,500 ISO International Standards are available on subjects in such diverse fields as information technology, textiles, packaging, distribution of goods, energy production and utilization, building, banking and financial services. ISO standardization activities include the widely recognized ISO 9000 family of quality management system and standards and the ISO 14000 series of environmental management system standards. Standardization programmes are now being developed in completely new fields, such as food safety, security, social responsibility and the service sector.

Mission. To promote the development of standardization and related activities in the world with a view to facilitating the international exchange of goods and services, and to developing co-operation in the spheres of intellectual, scientific, technological and economic activity.

Headquarters: 8 Chemin de Blandonnet, CP 401,

CH-1214 Vernier, Geneva, Switzerland.

Website: http://www.iso.org

Email: central@iso.org

President: John Walter (Canada).

\section{International Road Federation (IRF)}

The IRF is a non-profit, non-political service organization whose purpose is to encourage better road and transportation systems worldwide and to help apply technology and management practices to give maximum economic and social returns from national road investments.

Founded following the Second World War, over the years the IRF has led major global road infrastructure developments, including achieving $1,000 \mathrm{~km}$ of new roads in Mexico in the 1950s, and promoting the Pan-American Highway linking North and South America. The IRF works together with members and associates in 118 countries, promoting social and economic benefits that flow from well planned and environmentally sound road transport networks. It publishes World Road Statistics, covering over 200 countries and territories.

Headquarters: Madison Place, 500 Montgomery St., Fifth Floor, Alexandria, Virginia 22314, USA.

Website: https://www.irf.global

Email: info@IRF.global

Chairman: Abdullah A. Al-Mogbel (Saudi Arabia).

\section{International Seabed Authority (ISA)}

The ISA is an autonomous international organization established under the UN Convention on the Law of the Sea (UNCLOS) of 1982 and the 1994 Agreement relating to the implementation of Part XI of the UNCLOS. It came into existence on 16 Nov. 1994 and became fully operational in June 1996.

The administrative expenses are met from assessed contributions from its members. Membership numbered 168 in Feb. 2018; the budget for the biennium 2015-16 was US\$15,743,143.

The UNCLOS covers almost all ocean space and its uses: navigation and overflight, resource exploration and exploitation, conservation and pollution, fishing and shipping. It entitles coastal states and inhabitable islands to proclaim a 12-mile territorial sea, a contiguous zone, a 200-mile exclusive economic zone and an extended continental shelf (in some cases). Its 320 Articles and nine Annexes constitute a guide for behaviour by states in the world's oceans, defining maritime zones, laying down rules for drawing sea boundaries, assigning legal rights, duties and responsibilities to States, and providing machinery for the settlement of disputes.

Organization. The Assembly, consisting of representatives from all member states, is the supreme organ. The 36-member Council, elected by the Assembly, includes the four largest importers or consumers of seabed minerals, four largest investors in seabed minerals, four major exporters of the same, six developing countries representing special interests and 18 members from all the geographical regions. The Council is the executive organ of the Authority. There are also two subsidiary bodies: the Legal and Technical Commission (currently 24 experts) and the Finance Committee (currently 15 experts). The Secretariat serves all the bodies of the Authority and under the 1994 Agreement is performing functions of the Enterprise (until such time as it starts to operate independently of the Secretariat). The Enterprise is the organ through which the ISA carries out deep seabed activities directly or through joint ventures.

Activities. In July 2000 the ISA adopted the Regulations for Prospecting and Exploration for Polymetallic Nodules in the Area. Pursuant thereto, it signed exploration contracts with eight contractors who have submitted plans of work for deep seabed 